\title{
Antimicrobial Activity of Essential Oils Against Plant Pathogenic Fungi: A Review
}

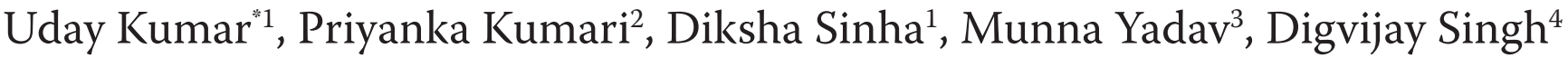 and Bipul Kumar Singh ${ }^{5}$}

${ }^{1}$ Department of Plant Pathology, Bihar Agricultural University, Sabour, Bhagalpur, Bihar, India

${ }^{2}$ Department of Fruit and Fruit Technology, Bihar Agricultural University, Sabour, Bhagalpur, Bihar, India

${ }^{3}$ Senior Research Fellow, ICAR-IINRG, Namkum, Ranchi, Jharkhand, India.

${ }^{4}$ Department of Plant Breeding and Genetics, Bihar Agricultural University, Sabour, Bhagalpur, Bihar, India

${ }^{5}$ Young Professional-II (Biotech KISAN Hub), Bihar Agricultural University, Sabour, Bhagalpur, Bihar, India

*Corresponding author: kumaripriyanka2k9@gmail.com

Received: 25 Feb., 2020

Revised: 13 Apr., 2020

Accepted: 25 May, 2020

\begin{abstract}
Essential oils are obtained from non-woody parts of the plants, particularly foliage, stem or hydrodistillation. They are complex mixture of terpenoids and variety of aromatic phenols, oxides, ethers, alcohols, esters, aldehydes and ketones that determine the characteristics aroma and odour of the donor plants. Presence of volatile monoterpenes or essential oils in the plants provides an important defense strategy to the plants, particularly against herbivorous insect pest and plant pathogenic fungi. Fungi cause huge amount of yield losses due to their ability to cause serious devastating diseases to the crops. Minimizing their effect on the crops need to get a promising way of controlling them. Therefore, the use of essential oils could be a good option to tackle the challenge of fungal diseases. Essential oils are natural products that are extracted from plants by different methods. They have been used for a long history of time for different purposes. Fungicides used in disease management are expensive for resource-poor farmers andnegatively correlation with ecosystems. Nowadays there is a huge interest to use them as plant protection product to be alternative for new agro-chemicals with large antimicrobial spectrum properties. As we observed from the antifungal trials in different literature, the essential oils have a great antifungal effect on many plant pathogens and inhibited most of the tested plant pathogens in the laboratory. Thus, essential oils could be a control agent for plant fungal diseases and further investigation is required to use in the field. This review summarized that the importance, antimicrobial activity and management of fungi.
\end{abstract}

Keywords: Hydrodistillation, aldehydes, ketones, antifungal, aroma, odour, terpenoids, fungi

In India about $75 \%$ of the population is involved in agriculture contributing about $40-45 \%$ of nation's income. Every economic crop cultivated in India is affected by at least one pathogen and even by a large number of pathogens and out of the 30,000 plant infections reported from different parts of the world more than 5000 are found in India. of these 5000 more than 1000 are directly affecting the economic crops. Because of the speedy growth of

How to cite this article: Kumar, U., Kumari, P., Sinha, D., Yadav, M., Singh, D. and Singh, B.K. (2020). Antimicrobial Activity of Essential Oils Against Plant Pathogenic Fungi: A Review. International Journal of Inclusive Development, 6(1): 37-44.

Source of Support: None; Conflict of Interest: None 
the world population, there is a growing demand for food, so it is necessary to tackle the challenges of food production including plants diseases. The plant disorders caused by fungi are the most devastating diseases in the agricultural farms, which causes huge losses to the yields of crops. In addition to that, there are many other significantly diseases caused by fungi, bacteria, virus, nematodes and phytoplasma to the plant. Management of plant diseases to decrease their effect are in urgent needs. Crop rotation, use of disease-free seeds, resistant varieties are among the control practices of plant diseases. Although chemical control measures are other important means to prevent plant diseases, their negative impact on the environment when it is used inappropriately made them unwelcomed all the time. When higher doses of chemicals are applied to the resistant varieties, it increases the level of toxic residues in the product (Daferera et al. 2003). Other disadvantages of intensive use of chemicals are the development of resistant strains of the target pathogen (Pasche et al. 2004). Nowadays it is known that there are various natural products from plants like essential oils those have the ability to suppress the growth of plant pathogens and reduce disease development, while they are safe to the environment and convenient as integrated pest management (Bowers and Locke, 2004). It can be said that EOs are non-phytotoxic in nature and safe for consumers. For seeking of economic and environmental sustainability, the use of products like essential oils over other chemicals has its own great value.
Essential oils are plant-based products that have potential use of different important matters of life. They are extracted from parts of the plant like leaves, flowers, roots, stems etc. In centuries, the people used them as a flavoring agent, aromatic requirements and medicinal purposes. Nearly 3000 EOs are known currently in which 300 of them are used in the flavoring and fragrance market (Burt, 2004). EOs contain multiple compounds that make their chemical, physical and biological properties (Regnault Roger, et al. 2012). It is believed that the EOs with good antifungal activity have phenolic or aromatic components in their chemical composition (Burt, 2004). Plants secrete these secondary metabolites to defend themselves against pest organisms (Amri, 2017). Thus, their antimicrobial and insecticidal activities are unnegligible. Previous researches mentioned that EOs could be a solution for plant pathogenic fungi and food associated fungi (Sitara et al. 2011; Parveen et al. 2010).

\section{Crop Protection by Chemical Methods}

Important fungal diseases occurring in various types of crops cultivated in India with their characteristics, estimated economic impacts and control measures are presented in table 1 . It is estimated that plant diseases alone cause monetary losses of worth ₹ 1560 crores annually (K T. Chand report). Methods used to control plant diseases varies according to the host plant, the kind of pathogen, the extent of their interaction and other environmental factors (Dale Walters, 2009). These methods can be generalized

Table 1: Important Fungal Diseases of Crops Cultivated in India [Booklet of K.T. Chandy]

\begin{tabular}{|c|c|c|c|c|}
\hline S1. No. & Crops \& Diseases & Pathogens & Infected parts & Significance \\
\hline 1 & Rice, Blast of rice & Pyricularia oryzae & $\begin{array}{l}\text { Leaf collar, culm, culm nodes, } \\
\text { and panicle neck }\end{array}$ & $\begin{array}{c}\text { In India, more than } 266,000 \\
\text { tons of rice were lost } 8\end{array}$ \\
\hline 2 & Wheat, Leaf rust & Puccinia recondita & Leaves and stalks & $\begin{array}{c}\text { Million tons of wheat is } \\
\text { damaged due to rusts only }\end{array}$ \\
\hline 3 & Sugar cane, Red rot & Colletotrichum falcatum & Leaves, whole cane & Epidemic fashion in India \\
\hline 4 & Mango, Anthracnos & Colletotrzchum gleosporzdes & Leaves, twigs, fruits & $\begin{array}{l}\text { Common in the states of } \\
\text { Punjab and Uttar Pradesh }\end{array}$ \\
\hline 5 & Banana & Fusarium oxysporum & Leaves & Economic loss \\
\hline 6 & Ginger, Soft rot & Pythium aphanidermatum & Leaves, rhizomes & Prevalent in south India \\
\hline 7 & Turmeric Rot & Pythium graminicolum & Leaves,roots rhizomes & South India \\
\hline 8 & Cotton wilt & Fusarium oxysponum & Seedlings & - \\
\hline 9 & Coffee Rust & Hemilia vastatrix & Leaves & Loss \\
\hline
\end{tabular}


into three namely cultural methods, methods using host plant resistance and chemical methods (Dale Walters, 2009). Cultural control method considered as the foundation of crop protection includes host eradication, crop rotation, sanitation, irrigation, tillage and improving growth condition (Dale Walters, 2009). Host plant resistance is defined as the collectable, heritable characteristics by which a plant species diminish the possibility of exploitation of that plant as a host by a pest or pathogen. (Dent, 1995). Use of resistant cultivars is one of the humblest and most convenient method of crop protection.

The control of crop diseases by chemical methods has a long history of more than a century [U. Gisi, 2009]. It extends from the first fungicide sulphur [http://www.melpat.com.au/documents/ TechNote_SulphurAsAFungicide_001.pdf] used against powdery mildew in grapes to the latest arrival named 'Emerald' (Boscalid, an Anilide) labeled for turf grass diseases like dollar spot and bentgrass dead spot (http://buckeyeturf. osu.edu/). Chemical agents especially fungicides belonging to the categories of Benzimidazoles, Cadmium Compounds, Carbamic Acid Derivates, Copper Compounds, Halogenated Benzenes, Organomercury Compounds and Phthalimides have become an integral part of the crop production in many parts of the world resulting in increased yield and income (U. Gisi, 2009). But later numerous environmental and ecological problems aroused by the over usage of fungicides (Hung-Chang Huanget al., 2009). For example, Methyl bromide, the effective soil fumigant for control of nematodes, fungi, insects and weeds in more than 100 crops worldwide had been later recognized as Class 1 stratospheric ozone depletory (W.M.O, 2003).

Many synthetic fungicides were found to generate side effects in nontarget organisms especially in soil affecting cell membrane components, protein synthesis, signal transduction, respiration, cell mitosis, and nucleic acid synthesis (Chao Yang et al. 2011). They are also found affecting earthworms which are the most important members of the soil profiling (Clive A. et al. 1992). Residues of fungicides have been found on food for human consumption, mostly from postharvest treatments (G.T Brook, 1999). Regular use of fungicides was realized as a serious menace to the environment, particularly when the residues persist in the soil or migrate to enter waterways to affect both terrestrial and aquatic ecosystems. For instance, long term use of copperbased fungicides results in the accumulation of copper in the soil which would adversely influence soil micro-organisms and long-term fertility of the soil (Wightwick et al. 2010) of some of the commonly used fungicides. A large number of fungicides had been reported for their adverse effects on domestic animals, wildlife, birds, honey bees, fish and aquatic invertebrates which is a serious issue as there is no specific treatment for fungicides poisoning in domesticated animals and humans (Hasan and Oruc, 2010). Above all the development or evolution of resistance in target organisms against fungicides pose a severe problem in agriculture, ecology and in all related fields (CABI, 2012). All the above discussed issues speed up the research for developing new antifungal agents which are cheap, devoid of side effects to non-targets and above all eco-friendly and green. Besides providing flavor and fragrance plant essential oils readily offer themselves as one of the best alternatives in this regard (Hammer and Carson, 2010).

\section{Essential Oils Extraction Methods from Plants}

There are several techniques used for essential oil handling from plant raw materials (Wang and Weller, 2006). Hydro distillation, steam distillation, solvent extraction, cold pressing, and microwave abetted hydro-distillation are the most commonly used methods of EOs isolation. Most of in vitro applications in the antifungal trials of essential oils that are going to be displayed here indicate that hydro-distillation method using Clevenger apparatus is a very common method of essential oil handling.

\section{Essential Oil's Mechanism of Action}

Factors that affect the activity of essential oils are their composition, functional groups present in their active components, and their synergistic interactions (Dorman and Deans, 2000). The antimicrobial mechanisms of action by the EOs vary in the type of the EOs and the strain of the microorganism used (Chouhan et al. 2017). Although the mechanisms that made essential oils effective as an antimicrobial agent are not fully known, there are numerous planned possible mechanisms. Researches revealed 
that accumulation of the essential oils in the cell, effect of cell permeability, disruption of major organelle membranes, alteration of the general morphology, (Hua et al. 2017; Bajpai et al. 2013; Tian et al. 2012), which causes leakage and death of the cell of the organism are the mechanism of action by the EOs. Concerning the antifungal activity particularly, their mechanism of action seems to involve penetration through cell walls and direct damage to both cytoplasmic and mitochondrial membranes (Bakkali et al. 2008). This causes changes in permeability which leads to leakage and finally results in the death of the cell (Bakkali et al. 2008). Iscan et al. (2016), reported extensive fungal cell wall and damage of cytoplasmic membrane after application of thymoquinone; a major component of the essential oil of black cumin seed. EOs could affect spore germination, germ tube elongation and inhibit the growth of fungal mycelia (Sivakumar, and Bautista-Baños, 2014). Formation of vacuole fusion in the cytoplasm, creation of numerous folding lomasomes, detachment of the plasma membrane from the cell wall and malformation of the fibrillary layers of the cell wall are the common alterations observed on the mycelia or fungal spores (da Cruzet et al. 2013).

\section{Characteristics and Potential of Essential Oils}

Essential oils are obtained from non-woody parts of the plants, particularly foliage, stem or hydrodistillation. They are complex mixture of terpenoids and variety of aromatic phenols, oxides, ethers, alcohols, esters, aldehydes and ketones that determine the characteristics aroma and odour of the donor plants. Presence of volatile monoterpenes or essential oils in the plants provides an important defense strategy to the plants, particularly against herbivorous insect pest and plant pathogenic fungi (Langenheim, 1994). Biologically, active essential oils represent a rich source of an alternative and perhaps, environmental more acceptable disease compounds. With a broad spectrum, safe antimicrobial action with significant economic and ecological benefits. These are natural fungicidal plant volatiles; numerous opportunities exist to explore their usefulness in controlling plant disease. The practical use of natural compounds as control agents is receiving increased attention and this is partly due to their nontoxicity and biodegradability
(Mason et al. 1996). Volatile compounds from plants, especially essential oils have been demonstrated to possess potent antifungal, antibacterial, insecticidal and nematocidal activity (Amvam Zollo et al.1998; Isman et al. 1999; Nguefack et al. 2005; Nguefack et al. 2007; Oka et al. 2000). Nevertheless, the use of essential oils as seed treatments for controlling seed-borne disease infection is promising (Adegoke et al. 1996; Montes-Belmont et al. 1998). Antifungal compounds present in the essential oil of $P$. graveolens include citronellol, geraniol, citronellyl formate and linalool (Ana et al. 2014). $\alpha$-citral, z-citral, limonene, caryophyllene, cerenl acetate, geraniol and citral are the main components of $C$. citratus oil (Farhang et al. 2013). The antifungal action of palmarosa oil is mainly attributed to its geraniol content. In addition to geraniol, geranyl acetate, linalool and $\beta$-carboxyphyllene have also been reported to possess antifungal activity (Anjali et al. 2003).

Mysore et al. (2014) found that the completely inhibition growth by using EOs when they tested the antifungal activity of cinnamaldehyde, eugenol, peppermint and clove EOs and their combinations against species of Aspergillus, Fusarium, Penicillium and Rhizopus in in vitro and tomato fruit system (In vivo) at or below $0.6 \%$ level (In vitro) and $80 \mu \mathrm{L}$ (in Tomato fruit) of EOs except peppermint oil. In a research done by Kordali et al. (2016), they found essential oils from fruits of four genotypes of Myrtuscommunis became very effective against nineteen plant pathogenic fungi and their antifungal effect was higher than benomyl; well-known commercial fungicide. Most of the laboratory experiments show the ability of essential oils to stop the growth of the pathogenic fungi, where some of them reveal fungicidal and some other fungi-static effect. The ability of the essential oil to act as fungicide or fungi-stat is dependent on its active compounds. As the intentions towards the use of essential oils as plant protection products increased the researches in this subject increased. Some of the studies that relate antifungal activities of the essential oils with their references are listed in the table below.

\section{Other Factors Affecting the Interaction of Components}

There are limited number of studies on the effects of the test medium physical and chemical 
Antimicrobial Activity of Essential Oils Against Plant Pathogenic Fungi: A Review $\mathcal{C}$

Table 2: Researches on Antifungal Activity of Essential Oil Against Different Plant Diseases

\begin{tabular}{|c|c|}
\hline Sl. No. & $\begin{array}{l}\text { Essential oils or plant species } \\
\text { extracted from them }\end{array}$ \\
\hline 1 & Carnation, Caraway, Thyme oils \\
\hline 2 & $\begin{array}{l}\text { Eucalyptus staigeriana, Eucalyptus } \\
\text { globulus, Cinnamomum camphora }\end{array}$ \\
\hline 3 & $\begin{array}{c}\text { Origanum vulgare L. ssp. hirtum) } \\
\text { Thymus vulgaris L. Citrus } \\
\text { limon L. }\end{array}$ \\
\hline 4 & Cestrum nocturnum L. \\
\hline 5 & Thymus leptobotrys \\
\hline 6 & Lippia alba (Mill.) N.E. Brown \\
\hline 7 & $\begin{array}{l}\text { Origanum onites L., Thymbra } \\
\text { spicata L., Lavandula stoechas L. } \\
\text { subsp. stoechas L., Foeniculum } \\
\text { vulgare Mill. Laurus nobilis L }\end{array}$ \\
\hline 8 & Commiphora molmol \\
\hline
\end{tabular}

9

10

11

12

13 Vitexagnus castus L. Myrtus communis $\mathrm{L}$.

$14 \quad$ Origanum acutidens and its components carvacrol, thymol p-cymene

15

Inhibited fungi

Altenaria solani

Alternaria solani

Botrytis cinerea, Penicillium italicum

$$
\text { P. digitatum }
$$

Colletotrichum capsici, Fusarium oxysporum, Fusarium solani, Phytophthora capsici, Rhizoctonia solani, Sclerotinia sclerotiorum

Penicillium digitatum, Penicillium italicum, Geotrichum candidum

Alternaria solani Soraue

Alternaria alternata

Aspergillus flavus, Cladosporium sp., Alternaria alternata, Fusarium oxysporum

$$
\text { F. solani }
$$

Fusarium solani, F. oxysporum, F. verticillioides F. proliferatum, F. subglutinans

Aspergillus niger, Aspergillus flavus, Penicillium sp.

Penicillium citrinum, Penicillium crustosum, Penicillium expansum, Penicillium griseofulvum, Penicillium brevicompactum

Lasiodiplodia theobromae, Fusarium oxysporum, Candida albicans

Myrtus communis L., Fusarium oxysporum $f$. sp. radicis-lycopersici (Sacc.), Rhizoctonia solani J.G.

Kuhn., Sclerotinia sclerotiorum (Lib.) de Bary, Verticillium dahliae Kleb.

Alternaria alternate Alternaria solani, Botrytis sp., Fusarium acuminatum, Fusarium culmorum, Fusarium equiseti, Fusarium nivale, Fusarium oxysporum, Fusarium sambucinum, Fusarium semitectum, Fusarium solani, Monilinia sp.,

Pythium ultimum, Phytophthora capsici, Rhizoctonia solani, Sclerotinia minor, Verticillium dahliae

Alternaria solani, Fusarium verticilloides, Fusarium semitectum, Fusarium culmorum, Fusarium proliferatum, Fusarium graminearum, Fusarium chlamydosporium, Fusarium sambucinum, Fusarium scirpi, Fusarium equiseti, Nigrospora oryzae, Phytophthora capsici, Phoma sp., Sclerotinia sclerotiorum, Sclerotonia sp., Sclerotium rolfsii

\section{Mode of References study}

In vitro and El-Mougy, 2009

In vivo

In vitro and Tomazoni et al. 2017 In vivo

In vitro and

In vivo Vitoratos et al. 2013

In vitro and

In vivo

Al-Reza et al. 2009

In vitro

Ameziane et al. 200

In vitro Tomazini et al. 2016

In vitro Soylu et al. 2015

In vitro

Perveen et al. 2018

In vitro

Gakuubi et al. 2017

In vitro

Mahilrajan et al. 2014

In vitro Felšöciová et al. 2015

In vitro Zheng et al. 2013

Yilar et al. 2016

In vitro Kordali et al. 2008

In vitro Kordali et al. 2013

In vitro

Bayar et al. 2018 
parameters on the interaction between essential oil components and their antimicrobial activities. Physical (temperature) and chemical (sodium chloride) parameters were also found to modulate the antimicrobial responses of the mixtures. Sodium chloride was found to have antagonistic effects when combined with carvacrol and p-cymene against B. cereus. It was also observed that carvacrol and p-cymene worked synergistically, but this effect was reduced when sodium chloride was added $(1.25 \mathrm{~g} / \mathrm{L})$. It has been reported that the combination of cinnamon and clove EOs showed better antimicrobial activity in vapor phase than in liquid phase In the study of the combined effects of thymol, carvacrol and temperature on the quality of non-conventional poultry patties by using a simplex centroid mixture design, the best effects were obtained when the patties were mixed with both compounds and stored at low temperature 0 to $3{ }^{\circ} \mathrm{C}$.

\section{CONCLUSION}

Essential oils are plant-based products that have a long history of use. They have promising action of antimicrobial and insecticidal effect. That is why EOs are used to test their activity by many researchers to see their potentiality for controlling fungal plant diseases. All the mentioned experiments in this review showed the high capability of the essential oils to act as antifungal agents. Their environmentally friendly characteristics make them interested by the researchers those exploring products that have desirable effects on the target organisms with no or less negative impact on the environment. The screening of oils as potential agents for plant disease control must be done on inoculated hosts. Certain phytopathogenic fungi grow well in the presence of various mineral oils, synthetic oils, and glyceride oils, yet these same oils control the diseases caused by the fungi. If oils are screened only against the pathogen in vitro, the results could lead to an erroneous conclusion that the oil will be ineffective, whereas, in fact, it may provide excellent disease control. Furthermore, a screening program should include oils that are relatively nonvolatile since this characteristic appears essential for the control of at least two diseases; banana leaf spot and septorial blight of celery. The classification of materials that control plant diseases generally reflects the mode of action involved, e.g., fungicides, fungistats, bactericides, protectants, chemotherapeutants, and the like. None of these categories is strictly appropriate for oils because of the following: (a) an oil may have several modes of action even against one disease; (b) unlike conventional compounds for disease control, the physical properties of oils (nonvolatility and nonmiscibility in water) appear more important than their chemical properties; and (c) oils control certain diseases caused by fungi and several caused by viruses. Therefore, to provide a name for oils adequately describing their broad and complex effects, I prefer the term "antidisease agents." Therapeutic. Currently, EOs are used mostly for food preservation and reduction of postharvest losses but it's believed in the near future they will be used in a broad category in many fields as bioproducts to avoid the problems encountered by the use of chemicals.

\section{REFERENCES}

Ameziane, N., Boubaker, H., Boudyach, H., Msanda, F., Jilal, A. and Ait Benaoumar, A. 2007. Antifungal activity of Moroccan plants against citrus fruit pathogens. Agron. Sustain. Dev., 27: 273-277.

Amri, J.E., Badaoui, K.E. and Haloui, Z. 2017. The chemical composition and the antimicrobial properties of the essential oil extracted from the leaves of Teucrium capitatum L. Asian J. Pharm. Clin. Res., 10: 112-5.

Bajpai, V.K., Sharma, A. and Baek, K.H. 2013. Antibacterial mode of action of Cudrania tricuspidata fruit essential oil, affecting membrane permeability and surface characteristics of food borne pathogens. Food Control, 32: 582-590.

Bakkali, F., Averbeck, S., Averbeck, D. and Idaomar, M. 2008. Biological Effects of Essential Oils-A Review. Food and Chemical Toxicology, 46: 446-475.

Bashir, U. and Tahira, J.J. 2012. Evaluation of Eucalyptus camaldulensis against Fusarium solani," International Journal of Agriculture and Biology, 14(4): 675-677.

Bayar, Y. 2018. Nohut Yanıklık Hastalı̆̆1 [Ascochytarabiei (Pass) Labr.]'nın Farklıİzolatlarına Karşı Mentha spicata L. Uçucu Yağının Antifungal Aktivitesinin Belirlenmesi. Türkiye Tarımsal Araştırmalar Dergisi, 5(2): 92-96.

Bowers, J.H. and Locke, J.C. 2004. Effect of formulated plant extracts and oils on population density of Phytophthora nicotianae in soil and control of Phytophthora blight 9 n the green house. Plant Dis., 88: 11-16.

Brooks, G.T. and Roberts, T.R. 1999. Pesticide Chemistry and Bioscience. Published by the Royal Society of Chemistry.

Burt, S. 2004. Essential oils: Their antibacterial properties and potential applications in foods-a review. Int. J. Food Microbiol., 94: 223-253. 
Chandy, T.K. Booklet No. 342, Plant Disease: Control: PDCS -4, http://www.inseda.org

Chao Yang, et al. 2017. ISRN Ecology, 2011 http://dx. doi. org/10.5402/ 2011/ 130289

Chouhan, S., Sharma, K. and Guleria, S. 2017. Antimicrobial Activity of Some Essential Oils-Present Status and Future Perspectives. Medicines., 4: 58.

Clive, A. 1992. Edwards and Patrick J. Bohlen, Reviews of Environmental Contamination and Toxicology, 125: 23-99.

Dent, D. 1995. Integrated Pest Management, Springer, pp-56.

Da Cruz, C.L., Pinto, V.F. and Patriarca, A. 2013. Application of plant derived compounds to control fungal spoilage and mycotoxin production in foods. Int. J. Food Microbiol., 166: $1 \mathrm{e} 14$.

Daferera, D.J., Ziogas, B.N. and Polissiou, M.G. 2003. The effectiveness of plant essential oils on the growth of Botrytis cinerea, Fusarium sp. and Clavibacter michiganensis subsp. michiganensis. Crop Prot., 22: 39-44.

Dale Walters, 2009. Disease Control in Crops: Biological and Environmentally-Friendly Approaches, John Wiley \& Sons, pp. 03.

Dale Walters. 2009. Disease Control in Crops: Biological and Environmentally-Friendly Approaches, John Wiley \& Sons, pp. 07.

Dorman, H.J.D. and Deans, S.G. 2000. Antimicrobial agents from plants: Antibacterial activity of plant volatile oils. J. Appl. Microbiol., 88: 308-316.

El-Mougy Nehal, S. 2009. Effect of some essential oils for limiting early blight (Alternaria solani) development in potato field. Journal of Plant Protection Research, 49(1): 1.

Felšöciová, S., Kačániová, M., Horská, E., Vukovič, N., Hleba, L., Petrová, J., Rovná, K., Stričík, M. and Hajduová, Z. 2015. Antifungal activity of essential oils against selected Terverticillate penicillia. Ann. Agric. Environ. Med., 22(1):3842.

Gakuubi, M.M., Maina, A.W. and Wagacha, J.M. 2017. Antifungal Activity of Essential Oil of Eucalyptus camaldulensis Dehnh. against Selected Fusarium spp. International Journal of Microbiology, Article ID 8761610, 7pages.http://dx.doi.org/10.1155/2017/87616 10.

Goñi, P., López, P., Sánchez, C., Gómez-Lus, R., Becerril, R. and Nerín, C. 2009. Antimicrobial activity in the vapour phase of a combination of cinnamon and clove essential oils. Food Chem., 116: 982-989.

Gisi, U., Ilan Chet Maria Lodovica Gullino. 2009. Recent Developments in Management of Plant Diseases, (Google e-Book), Springer.

Hammer, A.K.C.F. 2010. Carson in Chapter 11, Lipids and Essential Oils as Antimicrobial Agents edited by Halldor Thorma John Wiley \& Sons.

Hasan and Oruc. 2010. Fungicides and Their Effects on Animals, Fungicides, Odile Carisse (Ed.). http://www. intechopen.com/books/ fungicides/fungicides-andtheireffects-on-animals.200. http://www.knowledgebank.irri.org.

http://www.melpat.com.au/documents/ TechNote_ SulphurAsAFungicide_001.pdf

Hua, Y., Zhang, J., Kong, W., Zhao, G. and Yang, M. 2017. Mechanisms of antifungal and anti-aflatoxigenic properties of essential oil derived from turmeric (Curcuma longa L.) on Aspergillus flavus. Food Chem., 220: 1-8.

Hung-Chang Huang and Min-Tze Wu, 2009. Plant Pathology, Bulletin, 18: 112.

Iscan, G., Iscan, A. and Demirci, F. 2016. Anticandidal effects of thymoquinone: Mode of action determined by transmission electron microscopy (TEM). Nat. Prod. Commun., 11: 977--978.

Kalemba, D. and Kunicka, A. 2003. Antibacterial and antifungal properties of essential oils. Curr. Med. Chem., 10: $813-829$.

Keith Brent in Fungicide Resistance in Crop Protection: Risk and Management edited by Tarlochan S. Thindpp 1-13, CABI, 2012.

Kordali, S., Cakir, A., Ozer, H., Cakmakci, R., Kesdek, M. and Mete, E. 2008, Antifungal, phytotoxic and insecticidal proporties of essential oil isolated from Turkish Origanum acutidens and its three components, carvacrol, thymol and p-cymene, Bioresource Technology, 99: 8788-8795.

Kordali, S., Usanmaz, A., Cakir, A., Cavasoğlu, A. and Ercisli, S. 2013. In Vitro Antifungal Effect of Essential Oils from Nepetameyeri Benth. Egyptian Journal of Biological Pest Control, 23(2): 209-213.

Mahilrajan, S., Nandakumar, J., Kailayalingam, R. and Manoharan, NA. 2014. Screening the antifungal activity of essential oils against decay fungi from palmyrah leaf handicrafts. Biological Research, pp. 1-5.

Mastromatteo, M., Lucera, A., Milena, S. and Corbo, M.R. 2009. Combined effects of thymol, carvacrol and temperature on the quality of non-conventional poultry patties. Meat Sci., 83: 246-254.

Mohammadi, S. and Aminifard, M.H. 2012. Effect of Essential Oils on Pos-tharvest Decay and Some Quality Factors of Peach (Prunuspersica var. Redhaven). J. Biol. Environ. Sci., 6(17): 147-153.

Parveen, R., Azmi, A.M., Tariq, R.M., Mahmood, S.M., Hijazi, M., Mahmud, S. and Naqvi, S.N.H. 2010. Deterrmination of antifungal activity of Cedrus deodora root oil and its compounds against Candida albicans and Aspergilus fumigatus. Pak. J. Bot., 42(5): 3645-3649.

Pasche, J.S., Wharam, C.M. and Gudmestad, N.C. 2004. Shift in sensitivity of Alternaria solani in response to QoI fungicides. Plant Dis., 88(2): 181-187.

Perveen, K., Bokhari, N.A., Siddique, I.. and Rashid, S.A.I. 2018. Antifungal Activity of Essential Oil of Commiphoramolmol Oleo Gum Resin, Journal of Essential Oil-Bearing Plants, 21(3): 667-673.

Regnault-Roger, Vincent, C.C. and Arnason, J.T. 2012. Essential oils in insect control: Low-risk products in a highstakes world. Annu. Rev. Entomol., 57: 405-424. 
Reza, S.M., Rahman, A., Ahmed, Y. and Kang, S. CH. 2009. Inhibition of plant pathogens in vitro and in vivo with essential oil and organic extracts of Cestrum nocturnum L. Pesticide Biochemistry and Physiology, 96: 86-92.

Sitara, U., Hassan, U. and Naseem, J. 2011. Antifungal activite of Aloe vera gel against plant pathogenic fungi. Pak. J. Bot., 43(4): 2231-2233.

Sivakumar, D. and Bautista-Baños, S. 2014. A review on the use of essential oils for post-harvest decay control and maintenance of fruit quality during storage. Crop Protection, 64: 27-37.

Soylu, E.M. and Kose, K. 2015. Antifungal Activities of Essential Oils Against Citrus Black Rot Disease Agent Alternaria alternata, Journal of Essential Oil-Bearing Plants, 18(4): 894-903.

Stevic, T., Beric, T., Savikin, K., Sokovic, M., Godevac, D., Dimkic, I. and Stankovic, S. 2014. Antifungal activity of selected essential oils against fungi isolated from medicinal plant. Industrial Crops and Products., 55: 116-122.

Tejeswini, M.G., Sowmya, H.V., Swarnalatha, S.P. and Negi P.S. 2014. Antifungal activity of essential oils and their combinations in in vitro and in vivo conditions, Archives of Phytopathology and Plant Protection, 47(5): 564-570.

Tian, J., Huang, B., Luo, X.L., Zeng, H., Ban, X.Q. and He, J.S. et al. 2012. The control of Aspergillus flavus with Cinnamomumjensenianum Hand. -Mazz essential oil and its potential use as a food preservative. Food Chem., 130: 520-527.

Tomazini, E.Z., Pansera, M.R., Pauletti, G.F., Moura, S., Ribeiro, R.T.S. and Schwambach, J. 2016. In vitro antifungal activity of four chemotypes of Lippia alba (Verbenaceae) essential oils against Alternaria solani (Pleosporeaceae) isolates. Anais da Academia Brasileira de Ciências., 88(2): 999-1010.
Tomazini, E.Z., Pauletti, G.F., Ribeiro, R.T.S., Moura, S. and Schwambach, J. 2017. In vitro and in vivo activity of essential oils extracted from Eucalyptus staigeriana, Eucalyptus globulus and Cinnamomum camphora against Alternaria solani Sorauer causing early blight in tomato. Scientia Horticulturae, 223: 72-77.

Tongnuanchan, P. and Benjakul, S. 2014. Essential oils: extraction, bioactivities and their uses for food preservation. Journal of Food Science, 79: 1231-1249.

Ultee, A., Slump, R.A., Steging. G. and Smid, E.J. 2000. Antimicrobial activity of carvacrol toward Bacillus cereus on rice. J. Food Prot., 63: 620-624.

Wang, L. and Weller, C.L. 2006. Recent advances in extraction of nutraceuticals from plants. Trends Food Sci. Technol., 17: 300-312.

Wightwick, et al. 2010. Environmental Risks of Fungicides Used in Horticultural Production Systems, Fungicides, Odile Carisse (Ed.), http://www.intechopen.com/books/ fungicides/environmental-risks-offungicides-used-inhorticulturalproduction-systems.

World Meteorological Organization (WMO). 2003. Scientific assessment of ozone depletion: 2002 Global Ozone Research Monitoring Project Report. 47, Geneva., Switzerland, pp. 498.

Yilar, M., Bayan, Y. and Onaran, A. 2016. Chemical composition and antifungal effects of Vitexagnus-castus L. and Myrtuscommunis L. plants. Notulae Botanicae Horti Agrobotanici Cluj Napoca, 44(2): 466-471.

Zhang, Z., Han, X., Wei, J., Xue, J., Yang, Y., Liang, L.L.I. X., Guo, Q., Xu, Y. and Gao, Z. 2014. Compositions and Antifungal Activities of Essential Oils from Agarwood of Aquilaria sinensis (Lour.) Gilg Induced by Lasiodiplodia theobromae (Pat.) Griffon. \& Maubl. J. Braz. Chem. Soc., 25(1): 2026. 